\author{
ADEM ŞAHIN \\ (Konya, Turcja)
}

\title{
THE IMPACT OF MODERNIZATION AND SECULARIZATION ON INDIVIDUAL RELIGIOSITY: THE CASE OF TURKEY
}

Secularization as a process of Western origin is basically an attempt at freedom from the excessive authority of the Church and at narrowing the borders of religion. According to the theory of secularization, with the influence of modernization there occurs a breakaway from religious thought and practice, and even from the metaphysical conceptions in all realms of human life. First the human mind undergoes a process and then the determining and constructing role of religion in social system disappears (Aydın, 2001).

\section{Modernization}

Modernization is coined from the word modernus, which is derived from the Latin root modo, meaning "that is which of present or recent times." The term entered the English language as "modern" and was first recorded at the beginning of the $16^{\text {th }}$ century, simply meaning "being at this time and now existing."

In the later $16^{\text {th }}$ century, however, we begin to see the word contrasted with the word ancient and also used of technology in such a way as is clearly related to our own modern way of using the word. The term is now employed to refer to the mode of social life and organization that first arose in seventeenth century Continental Europe and then prevailed all over the world. (http://www.thefree dictionary.com/modern)

Derived from the same root, modernism denotes the comprehensive project that dates back to the Renaissance and aims at rationalizing the universe, culture, and human behavior. Thus, modernism means "the replacement of supernatural 
powers and designs with nature laws and human actions in the formation of nature and the man-nature relations" (Beşer, 2001).

Modernization, however, refers in social sciences to the process of evolution from the traditional into the modern society. Auguste Comte, one of the pioneering theoreticians of modernization, holds that humanity has arrived at positive stage by passing through theological and metaphysical stages. According to this view that also underlies the thesis of secularization, modernity is a universal process that involves secularization, too. As a result of modernization, there occurs a partition from religious thought and practices, and even from the metaphysical conceptions in all realms of human life. First the human mind undergoes this process and then religion loses its determining and constructing role in the whole social system (Aydın, 2001).

A look into the adventure of the term modernization reveals that the term has undergone a semantic change over time so as to denote the transformation of non-Western societies in the direction of Westernization in political, social, economic, cultural and religious sense. Accordingly, Western societies have reached the positive stage which was posited by Comte as the last stage of human development. The non-Western societies that are also called "the Third World", too, can only reach this ultimate stage by following in the footsteps of the West. According to its proponents, this process shall take place in its natural course in some societies while it should be realized in others either by internal dynamics or through foreign intervention (Okumuş, 2007).

\section{Secularization}

The term secularization is derived from the Latin root seaculum that means "the present age" and "the present time". It designates the events and facts that are related to the present age. Thus, the emphasis is upon the state of the world in a particular time and period, denoting this worldliness.

Secularization marks a process in which especially in industrialized societies the religious beliefs, practices and institutions have lost their former social importance; the traditional beliefs are subjected to rational questioning; the monopoly of religious symbols is broken with the pluralization of the life spheres; and, people have established more control on their environment with the rise of individualism (Wilson, 1983, p. 148).

The validity of the thesis of secularization as a process that had been a prevalent discourse for about three centuries have been questioned since the 1960 s by social sciences in general and by sociology in particular. 
The advocates of the thesis of secularization hold that modernity shall absolutely give birth to secularization and consequently religion shall decline in social and individual consciousness, eventually disappearing from the agenda of mankind. This thesis is held by some thinkers on the grounds of the decrease in the number of Church-goers. Of them, one can mention Steve Bruce, the author of God is Dead, as well as Bryan Wilson and Karel Dobblear in the first place.

On the other hand, many leading scholars such as Peter Berger, Rodney Stark, Daniel Bell, and Jeffry Hadden reject the thesis of the irreconcilability of modernity and religion. For them, the decrease in the number of Church-goers cannot be taken as the sign and gauge of the rise of secularization. Though many Christians fail to attend the Church, this does not mean their break from religion, for they continue to believe in the existence of God and the spirit though they fail to go to the Church and have no ecclesiastical affiliation. Grace Davie explains and terms this situation "believing without belonging." As an example for this, one can mention the case of Iceland, which is accepted to be the most secular country in the world, because the rate of the Church-goers to the general population in this country is just $2 \%$ while $81 \%$ believe in the afterworld and $88 \%$ in the existence of the spirit. As for the rate of the atheists, it is only 2,4\%. From this it follows that people preserve their individual bound with religion though they have no ecclesiastical affiliation. The modernized Far Eastern societies, too, can be given as example because the occult religions survived the wave of modernization therein.

Along with the pro-secularist and anti-secularist views described above, we observe the rise of a third perspective. Spearheaded by such scholars as Mark Chaves, David Yamane, Conrad Oswalt, and Jose Casanova, this new conception posits modernity and religion as interacting with each other. For them, religion has not disappeared from the agenda of mankind, yet it has been influenced by secularization to a certain extent. Religion dropped its institutional character, undergoing an evolution in the direction of spirituality. As a result of secularization, new religious conceptions have appeared, and religion has undergone a formal change. From this it follows that secularization has not terminated religion but ushers in a change in the concept of religion (Köse, 2006, p. 12-14).

\section{The Impact of Modernization and Secularization on Individual Religiosity}

As it has been already pointed out, the proponents of the thesis of secularization maintain that religion shall either disappear as a whole or lose much of its power, only continuing its existence in a limited scope as a result of 
modernization and the resultant secularization. Though there are some findings that support this view, the developments show that the things do not go as were expected and there is a noticeable growth in the return to the sacred. The new period that we observe especially after the 1960s is called the epoch of the great religious awakening, the new religious awareness, the oriental religious awakening, and the re-establishment of religion. From the 1960s onward, these new developments in the realm of religion have appeared especially in Western societies as oriental religions, traditional religious teachings, mystical beliefs, and magical and neo-pagan trends.

The noteworthy point is that this interest in religion manifests itself not only as appeal to great religions but also as varieties of spirituality that stress individual experience vis-à-vis these religions and creative innovation and hybridism vis-à-vis tradition. We observe a growing interest in magical currents, mystical and spiritual teachings, and new religious trends in addition to traditional religions such as Islam, Christianity, and Buddhism (Arslan, 2010).

In what follows, we shall give some examples of the new orientations to religion and then proceed to analyze the processes that underlie this new situation.

\subsection{Magical and Mystical Trends}

Max Weber posited the "disenchantment of the world" as one of the most important consequences of modernism. This notion designates clearing political and religious systems from sacredness and mysticism. Accordingly, disenchantment means overrationalization and cultural transformation as a result of which religion lost most of its importance.

The findings and observations of social scientists as well as the studies done in various fields show that there is a rise in religious and magical trends in today's modern societies especially in the recent years. One of the underlying factors for this rise is the process of overrationalization that boosts the thirst for spirituality.

In parallel with the developments described above, we observe that in both developed countries and Turkey there have appeared small social organizations of magical and mystical character; the books, novels, and films of magical and mystical themes received a warm welcome from a considerable size of audience, reaching a high circulation. A great number of people, including children and youngsters, read the following literature many times and watch again and again the films based on the novels they had read.

For example, the novels and films of Harry Potter, telling of the adventures of a young magician, are reflected into the imagination of millions of people, becoming a "myth" of modern times, as it were. Likewise, we see that many extraordinary and paranormal mystical themes have been treated in a religious 
and philosophical color in such films as the Lord of the Rings and the Matrix. Along with the films about the invasion of earth by extraterrestrial beings such as the Signs, Alien, Ghost, and the Sixth Sense, as well as such films about the paranormal, religious themes as Exorcism, the Exorcism of Emily Rose, and the Omen have enjoyed a massive interest. And even the occasional re-shootings of these films attract a good number of viewers.

In parallel to this trend in the world, we see that there have been produced many films with paranormal religious motifs in the last ten years in Turkey such as Okul (the School, 2004), Büyü (Magic, 2004), Dabbe, (the Beast, 2005), Araf (the Isthmus, 2006), Gen (the Gene, 2006), Küçük Kryamet (the Lesser Doomsday, 2006), having met with the Turkish audience. In addition, we see the appearance on Turkish TVs of the serials of religious contents that we call "mystery serials" such as Sirlar Dünyası (the World of the Mysteries), Kalp Gözü (The Eye of Heart), and Sir Kapısı (the Gate of Mystery) as well as the following serials which can be categorized in the same genre though they have a differing motif: Strların Efendisi (the Lord of the Mysteries), Sihirli Annem (My Magic Mom), Tatlı Cadı (Sweet Witch), and Selena (Arslan, 2006, 2010).

\subsection{Paganistic Trends}

Paganistic trends that waned and became obsolete with the advent of monotheistic religions have begun to re-appear nowadays with the rise of spiritual ways of life, mystical and fantastic stories, and environmentalism. What underlie all these developments are the priorities, the ways of life, and the beliefs that have emerged due mostly to the influence of modernization and secularization.

The aforementioned films, serials, and novels that are inspired by the fantastic pagan culture of magicians, gods, and goddesses have turned pagan cults and rites into a modern phenomenon. As a result, we much more frequently than before come across the paganism-inspired dances, music, makeups, tattoos, and spiritual development books, programs, and courses. The environmentalist trends and the sense of responsibility towards nature that have recently become more noticeable in consequence of the global warming seem to feed the paganistic trends.

On the other hand, the recent inquiries show that there is an increase not only in the number of those who display paganist inclinations but also in the number of those who adopt Paganism as a belief proper in the developed Western countries like the US and England. For example, the inquiries about Paganism in England reveal that the number of the followers of Paganism has exceeded 250.000 as of the year 2009, a figure equaling the Jewish and doubling the Buddhist population in the country (Moreton, 2009). Again the investigation reports show that there 
are 768.400 Neo-paganists in the US as of the year 2000, and a nationwide inquiry performed on youth and religion that consists of 3370 subjects finds out that the rate of the paganist youth triples the general population. Thus, Paganism is expected to be the third largest "religion" after Christianity and Judaism in 2012 in the US (http://www.adherents.com/rel_USA.html). As far as we know, there is no group in Turkey who declare themselves to be Pagan. However, we see that there is an agency affiliated to Pagan Federation International that makes online subscription to the Federation (http://www.tr.paganfederation.org).

Though there is no group in Turkey who declare themselves to be pagan, we know that there have been paganist inclinations among Turkish people since the old times and these inclinations have become more apparent in recent years. It is thus the paganist inclinations that underlie such traditional Turkish rituals and cults as the Nevruz celebrations, the cult of jumping across the fire, the Hudırellez celebrations, visitations of shrines, wish trees, the tying of strips of cloth to the tree, and the wearing of evil eye beads as well as such phenomena of Western origin that have now become quite familiar to Turkish people as the new year celebrations, the figure of Father Christmas, decorating the pine tree, the celebrations of Halloween and Valentine's Day. Such celebrations and practices have become so familiar that they are organized even at kindergartens, and there have been held activities and balls, the marketplaces being decorated weeks ago to enhance and reflect the atmosphere of these activities.

So, what are the reasons behind the rise of paganist trends? According to the observations and analyses, what underlies the growing interest in paganism particularly in the industrialized Western societies is spiritual dissatisfaction, materialism, ecological concerns, the quests of the people dissatisfied with their traditional religion, and the spiritual vacuity generated by materialism (Arslan 2006).

\subsection{The Trend of Believing as Living}

The statement, "If one fails to live as he believes, he starts to believe as he lives", attributed also to "Umar, the second Rightly Guided Caliph, succinctly expresses a good part of the experiences that the Muslims face due to the influence of modernization and secularization.

The change that we experience as a result of modernization is in part the reversal of the subject-object relation by the religious Muslims. Started with the Enlightenment, the process is that man, who had been in the position of the object vis-à-vis nature, rose to the position of the subject. Though this change of roles is taken to be a positive development in some respects, this relation seems to 
have reversed again. Man controls the things for a limited period of time, but then he comes under the sway of the things and environment, falling to the position of the object.

Defining itself as the middle road, Islam clarified man's relation with the things. It approves neither of withdrawing from the world altogether nor attaching too much attention to it. This principle is best enunciated by the saying that is uttered by 'Abdullah bin 'Amr bin al-As, a companion of the Prophet Muhammad, though it is also claimed to be a Prophetic tradition, "Work for the world as if you will never die and work for the Hereafter as if you will die right tomorrow." Again according to Islam, the world is the Hereafter's farm and we shall reap there what we sow here, many Qur'anic verses and Prophetic traditions preaching to lead an otherworldly life. This is the way Islam looks on the world notwithstanding, it is observed that the excessive and insisting emphasis of modern life on this world influences the religious people, too, though this emphasis is not particularly modern.

The profanation of religious people takes place in a threefold process: First their behavior changes, then their mindset undergoes a transformation, and finally their behavior assumes a new structure in parallel to this new cognitive mechanism. This appears first as an effort to raise the life standard and lasts as that of keeping and advancing the standard, and after a while the worldly things turn into the ends. In the meantime, the previous religious sensitivity grows weaker and soon later the individual takes resort to certain defense mechanisms in attempt to legitimize some of his experiences. In result, while the beliefs were at the center of personality and the worldly things in the periphery in the beginning, later on the latter supersedes the former and a cognitive re-structuring takes place in this parallel.

As an example for the orientations that shift from the periphery to the center and subsequently influence the individual's religious life, we can mention the following trends:

The desire of accumulating goods: Whereas a religious person initially observes such religious and moral principles as making money in lawful ways and avoiding the unlawful ones and keeping away from profligacy in expenditures, later on he tries to earn more and more money regardless of whether it is lawful or unlawful; the fact that the workplaces and malls turn into modern temples.

The way of dressing: Whereas a religious person strictly observes the religious codes of dressing in the beginning, later on he earnestly follows the fashion to the extent that there appears a special fashion that is called "religious"; seeking after the nice clothes; trying to have a very rich wardrobe while he was content with modest one previously, considering it necessary to renew his whole wardrobe every year even if he wore them only few times. 
The contest of having bigger and more luxurious homes and cars: While in the beginning a religious individual has a house that is humbly and even poorly built, furnished and decorated, and regards the high buildings as the omen of Doomsday, later on he considers the larger, higher and more luxurious houses as the sign of wealth and status, viewing it as his due right to acquire them, and seeking after summer and winter houses, and even after the houses that he would never dwell in.

The spread and normalization of lying: Rendering and considering the telling of lies an innocent action by painting them in various colors in all realms of life.

Turning worship into hypocrisy and quitting worship over time: Turning the giving of charity into TV shows, pilgrimage into touristic trips, forming kilometer-long convoys of cars to bid farewell and welcome to the pilgrims, and turning their return into the welcoming ceremonies.

Giving priority to work over worship: Failing to perform the ritual prayers in time, quitting first the supererogatory and then the obligatory prayers, seeking favorite religious legal opinions, and looking for the clergymen who would issue such religious opinions.

Showiness outweighs the needs: Showiness prevails over the needs and wishes; paying too much attention to what people think about one's eating, drinking, dressing, worshipping, etc.

In addition to the examples above, the subject-matters of the legal inquiries that are raised and answered on the newspapers columns that are dedicated to the issuing of religious opinions show strikingly the agenda of the modern man and the impact of modernization: Should one pay the obligatory alms for the house that one bought with bank credit? Is it lawful to perform pilgrimage to Mecca with bank credit? Is clandestine marriage lawful? Is it lawful to pray when one is drunk? Is it lawful to put on a necklace on which the Throne Verse is inscribed? What is the religious status of the exchange of presents on Valentine's Day?

\section{Assessment and Conclusion}

One might ask, what are the processes underlying the trends that have been observed in the individual's religious life? Why do there appear such new trends and forms of religiosity? What parts do modernization and secularization play in the rise of these trends?

One may identify the spiritual crises and the quests of meanings that befall modern man as one of the underlying reasons for the rise of the beliefs and trends of which the examples we have cited above and that we can corroborate through more examples. The speedy process of transformation that has arisen 
as a consequence of modern life combines with the technology-centered social mechanism and individualization to give rise to a spiritual vacuity which in turn prepares the ground for the rise of new belief movements.

The widespread mass media and particularly the Internet easily deliver the offers of healing, salvation, peace, and happiness hailing from various sources to the people who grow up in a too rational world and interpret the meaning of life in a secular way, experiencing the problem of meaninglessness of life. The loss of meaning caused by the process of overrationalization has brought about a belief explosion in disenchanted societies, as it were. Religiosity has revived by assuming various forms and the quasi-religious beliefs, practices and organizations have become the source of reference for people in their quest of meaning (Arslan, 2010).

On the other hand, the facts of individualization and subjectivization, both coming to the foreground as concomitant of modernization, as well as religious pluralism that is integral to the first two though it seems contrary to them, are also noteworthy phenomena. Individualization and subjectivization keep in distance from the traditional religious institutions, on the one hand, and give birth to new models of religiosity that give priority to the individual, on the other. These forms of religiosity, however, do not remain limited to individual level; on the contrary, they set the stage for the rise of various religious groups by gathering together those who have similar thoughts and ways of life. These new social structures for which magical, mystical and spiritualist groupings can be given as example reject the authority of traditional religious institutions, on the one hand, and form new organizations that incorporate the individuals into a social body, on the other. In fact, we have an action-reaction relation in this context. Accordingly, inasmuch as rationalism grows stronger, people more frequently appeal to the mystical, the magical, and the religious; subsequently, the disenchanted world as termed by Weber becomes enchanted again.

In conclusion, the experiences that are lived in both Western and nonWestern societies support only a small part of the theses of modernism and secularism while the same experiences invalidate much of these theses. Looking from the perspective of traditional religions, we see that though religion has kept its influence in non-Western countries to some extent, it, however, has lost much of its vigor, being superseded by the anthropocentric secular institutions and concepts.

On the other hand, modern life has given rise to new forms and trends of religiosity that have an individualistic character. We see that the modern man, who is reluctant to follow an absolute authority but seeks, at the same time, a haven to take refuge from the chaos of the present life, shows interest in new religious trends and tries to find spiritual sources, religious and non-religious, to fill his spiritual vacuity and answer his quest of meaning. 
As far as Turkey is concerned, we can say that though the process of modernization and secularization have begun to change the way people, including the religious ones, look on the world though not to the same extent in the West; the new individualist social structures become increasingly conspicuous, and this leading in turn to loneliness, lack of meaning, and spiritual vacuity. People experiences new problems in modern age and develop different defense mechanisms to adapt themselves to the new conditions, and as a result, there appear new conceptions of religiosity that did not exist in traditional social structures.

\section{Summary}

The purpose of this paper is to investigate the impact of modernization and secularization on individual religious life, as well as to describe the newly emerged conceptions of religiosity and the psycho-sociological processes underlying them in the scope of Turkey. In this context, I shall first deal with the concepts of modernization and secularization, then give a few examples of the new religious trends that have arisen as a result of modernization and secularization, and finally analyze the psycho-social processes that underlie them.

\section{Bibliography}

ARSLAN, Mustafa (2006). Değişim Sürecinde Yeni Dindarlık Formları: "Yeni Çă̆" İnanışları Örneği, Dĕ̆erler Eğitimi Dergisi, 11, p. 9-25.

ARSLAN, Mustafa (2010). Seküler Toplumlarda Kutsal Arayışları: Geç Modern Dönemde Büyü-Din İlişkisinin Sosyolojik Analizi, İ. Ü. İlahiyat Fakültesi Dergisi, Spring, 2010/1(1) p. 195-210.

AYDIN, Mehmet S. (2001) Dünyevileşme, Islamiyat, 3, p. 13-17.

BEŞER, Vehbi (2001). Modernizm ve Potmodernizm Arasında Kutsalın Yitirilişi, İslamiyat, 3, p. 59-79.

KAPLAN, Yusuf (2001). Seküler Aklın Ötesi, İslamiyat, 3, p. 81-102.

KÖSE, Ali (2006). Sekülerleşme Teorileri Bağlamında Türkiye'de Din Ve Modernleşme, Laik Ama Kutsal, ed. by Ali Köse, Etkileşim Yayınları, İstanbul.

MORETON, Cole (2009). Everyone's A Pagan Now, The Guardian, Monday, June 22.

OKUMUŞ, Ejder (2007). Modernleşme, Sekülerleşme ve Din, Kamu Hukuku Arşivi, 10, 1, p. $1-22$.

WILSON B. R. (1983). Religion in Sociological Perspective, 2nd Edition, Oxford University Press, Oxford-New York. 
"Largest Religious Groups in the United States of America", http://www.adherentp. com/rel_USA.html, reach date, 01.05.2011.

"Modern". http://www.thefreedictionary.com/modern, reach date, 10.04.2011

http://www.tr.paganfederation.org/index.php

Adem Şahin holds a Ph.D. in Psychology of Religion, and is associate professor at Theology School of Necmettin Erbakan University, Turkey. 